\title{
Strategy for Maximizing Customer Lifetime Value: A Study on Fairness Cream Users of Bangladesh
}

\author{
FAYEZ AHMED \\ MOHAMMAD AFSAR KAMAL ${ }^{* *}$
}

\begin{abstract}
Customer lifetime value is one of the most important concepts in marketing on which lots of scholarly writings have been done to analyze this concept. In this study, we have used this concept to study fairness cream market of Bangladesh. Through this study we have tried to find out the factors that increase customer lifetime value in fairness cream market. To conduct the study, we have used simple random sampling technique where 300 respondents have been interviewed. We have utilized multiple regression technique to analyze the data. The findings that have been generated from the analysis is that fairness cream companies can increase customer usage months of fairness cream product or customer lifetime value through proper application of three factors which are creating fear that experimentation may be dangerous for skin, strong positioning that user's brand is the best brand in the market and marketer's brand has international recognition.
\end{abstract}

Keywords: Customer Lifetime Value, Customer Satisfaction, Net Present Value, Customer Profitability, Customer Acquisition, Customer Retention

\section{INTRODUCTION}

In today's competitive world, business organizations are looking for new and diversified ways to survive and prosper in their business arena. The prominent business organizations are looking for all the options and trying to implement some important theories in the marketplace. Marketplace itself is dynamic and some theories that were proven effective for one particular time became obsolete at another time. So marketers are very much cautious about applying business theories. Despite this cautiousness, organizations will never ignore some theories because of their prominence and the theory on customer lifetime value is one of them. Measuring customer lifetime value and also maximizing customer lifetime

\footnotetext{
* Lecturer, Department of Marketing, Bangladesh University of Business \& Technology (BUBT). Mirpur -02, Dhaka -1216. Email: fayezahmed004@ yahoo.com

** Senior Lecturer, Department of Business Administration, Uttara University (UU). Uttara, Dhaka-1230. Email: kamal.coxi@yahoo.com
} 
value are two very important aspects for today's business organizations. Before knowing the technique of measuring and maximizing customer lifetime value, one should have in-depth knowledge about customer lifetime value. Kotler (2011) states, "Customer lifetime value (CLV) describes the net present value of the stream of future profits expected over the customer's lifetime purchases ( $p$. 132)." From the Kotler's definition, it can be said that companies will have to measure the net present value (NPV) of future profits that will be generated from customer's future purchasing in order to measure customer lifetime value. Kotler (2011) again states, "The Company must subtract from its expected revenues the expected costs of attracting, selling, and servicing the account of that customer, applying the appropriate discount rate (say, between $10 \%$ and $20 \%$, depending on cost of capital and risk attitudes)."

Because of its importance, a wide variety of industries are trying to use and capitalize this concept and fairness cream industry is one of the industries. "Historically, in South Asia fairness pale skin is considered as social markers of aristocratic lineage and class allegiance. Dark skin is associated with labor and field-work in the Sun. 'White' skin has a colonial notion of power and superiority." (Shankar P. R. and Subish P. 2007)

So Bangladesh, as a part of South Asian region has a strong and high growth market for fairness cream producers. Fairness cream companies of Bangladesh should keep their eyes open to measure and maximize customer lifetime value because like the customers of all other countries, profitability from Bangladeshi customers increases as their lifetime progresses. As a result, efficient application of this concept will give Bangladeshi companies a great tool to maximize their profitability by reducing the cost to serve customers.

As this concept (customer lifetime value) is important for local companies, they should implement this concept but they have been ignorant about it. Knowledge about what are the important variables to make lifelong customers and the variances among the degrees of importance among the important variables.

This study has been conducted to understand the above-mentioned conceptual issues and to make today's companies more customer centered and to give them the idea of increased profitability from increased customer lifetime value. In this study, the main focus is on the factors that make customers to stay with their existing companies for longer time. It is intended that the present research will generate some findings on CLV which will give business organizations some definite set of ideas how to make their customers more loyal. 


\section{LITERATURE REVIEW}

Lifetime customer is very important to today's companies because of the value that companies get from the customers over their lifetime. It's an important number because it shows you that it's worth investing in capturing customers! Sure, it may cost you $\$ 100$ to capture one customer, but that customer may be worth $\$ 10,000$ or more to you over a lifetime. That's a transaction worth doing over and over! (www.franchisemastermind.com/). World's leading companies are very much concerned about this topic and these companies are constantly trying to improve their position on this issue. Customer lifetime value (CLV) is gaining increasing importance as a marketing metric in both academia and practice. Companies such as Harrah's, IBM, Capital One, LL Bean, ING, and others are routinely using CLV as a tool to manage and measure the success of their business (Gupta et al. 2006).

\section{MODELS OF CUSTOMER LIFETIME VALUE}

Customer lifetime value has been the topic of discussion for many years. Scholars have developed different types of models to measure the customer lifetime value and also to measure the outcome of customer lifetime value. The modeling of customer lifetime value gives the basic idea about how customer lifetime value can be measured and it also shows the construction of the measurement of customer lifetime value through the modeling of different factors of this approach.

The authors of this model focus their attention on three components from the total of 10 components and they consider these three as very important components which has been clear from the following statements of V. Kumar and Bharath Rajan:

"This model the CLV framework can be modeled using three main components: contribution margin, marketing cost, and probability of purchase in a given time period. Each of these models has a set of drivers and predictors, and the models are estimated simultaneously. By applying this modeling approach, managers can estimate the CLV for each customer of the firm." 


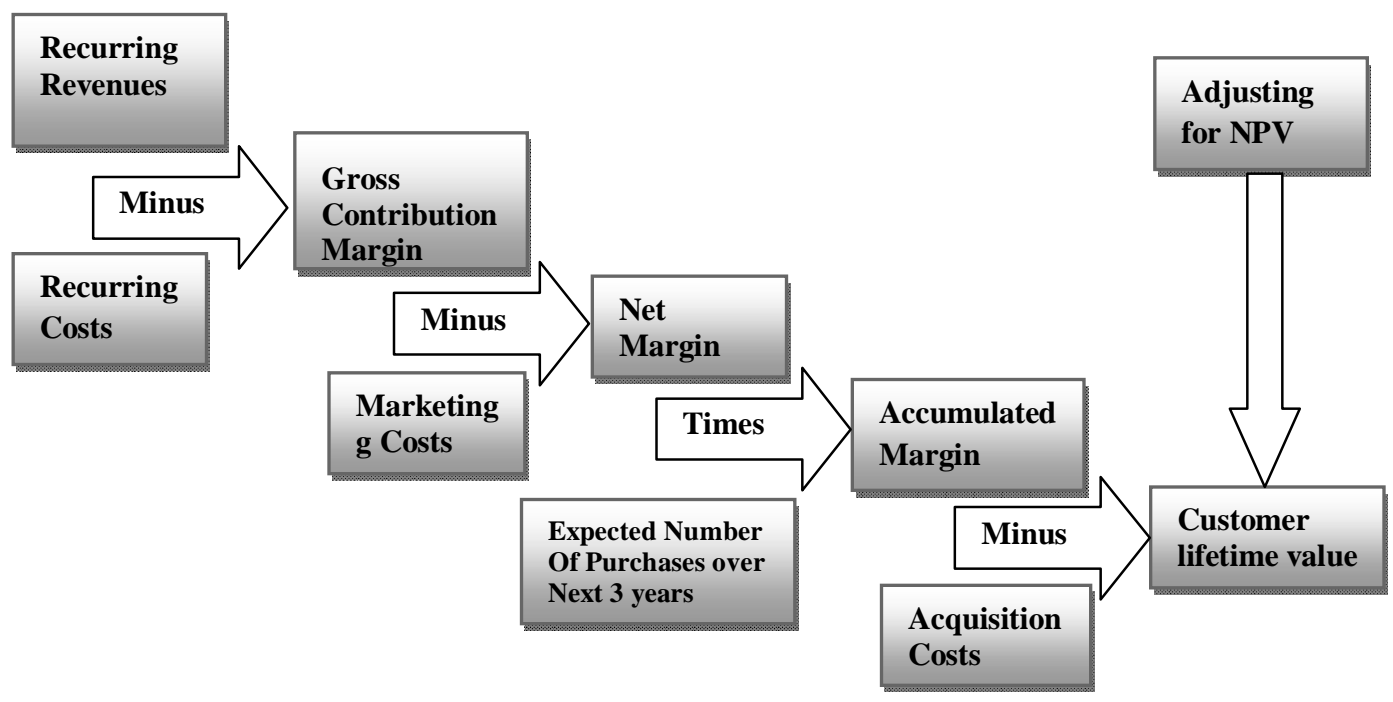

Source: Adapted from V. Kumara and Bharath Rajan (2009)

The calculation of CLV for all customers helps the firm rank customers on the basis of their contribution to profits. This would help firms in developing and implementing customer specific strategies that can maximize customer lifetime profits and lifetime duration. In other words, CLV helps the firm treat each customer differently, based on his or her contribution, rather than treating all customers the same.

In fairness cream market of Bangladesh, companies like Unilever, Kohinoor, $\mathrm{P} \& \mathrm{G}$, and Botanic etc can use this concept where they can find out the outcome of customer lifetime value. Reinartz, Jacquelyn and Kumar have shown a positive relationship between customer lifetime value with customer profitability which in turn results in company profitability. 


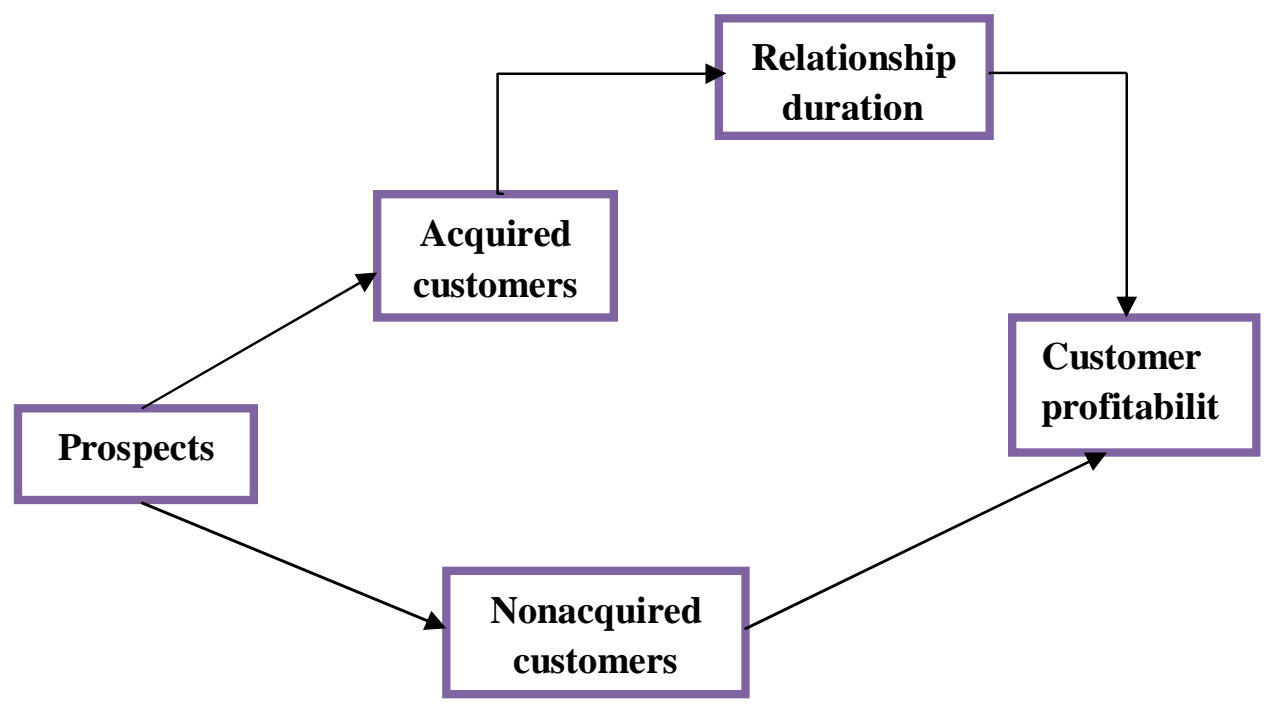

Acquisition process

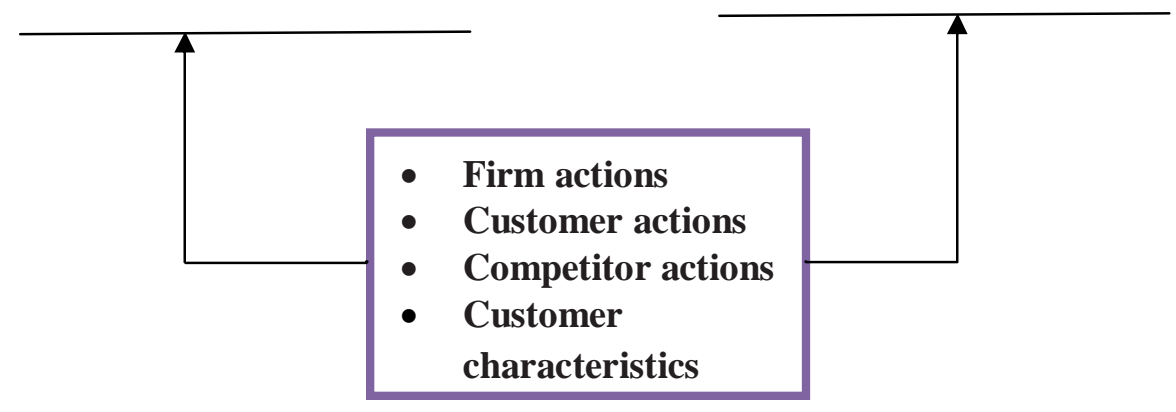

Source: Adapted from Werner Reinartz, Jacquelyn S. Thomas, \& V. Kumar (2005)

\section{Calculation of customer lifetime value (CLV)}

Calculation of customer lifetime value is another important step for global marketers in order to determine the differences among the customers in terms of the profitability factor. Calculation of customer lifetime value allows us to differentiate between customers who are more profitable than others rather than simply examining average profitability (Gupta et al. 2006). CLV for a customer (omitting customer subscript) is (Gupta, Lehmann, and Stuart 2004; Reinartz and Kumar 2003): 
$\mathbf{C L V}=\boldsymbol{\Sigma} \quad \frac{\mathbf{T} \quad\left(\mathrm{p}_{\mathrm{t}-\mathrm{c}}\right) \mathrm{r}_{\mathrm{t}}}{\mathbf{t}=\mathbf{0} \quad(\mathbf{1 + i})^{\mathrm{t}}} \quad-\mathbf{A C}$

Where,

$p t=$ price paid by a consumer at time $t$,

$c t=$ direct cost of servicing the customer at time $t$,

$i=$ discount rate or cost of capital for the firm,

$r t=$ probability of customer repeat buying or being "alive" at time $t$,

$A C=$ acquisition cost, and

$T=$ time horizon for estimating CLV

In spite of this simple formulation, researchers have used different variations in modeling and estimating CLV (Gupta et al. 2006). Some researchers have used an arbitrary time horizon or expected customer lifetime (Reinartz and Kumar 2000; Thomas 2001), whereas others have used an infinite time horizon (e.g., Fader, Hardie, and Lee 2005; Gupta, Lehmann, and Stuart 2004). Despite the differences among the researchers regarding the time horizon in calculating customer lifetime value, both the approaches are logical and can be used to calculate CLV.

\section{RATIONALE OF THE STUDY}

Bangladeshi fairness cream market consists of some national and international organizations that are following different strategies to improve the market position like conducting promotional program, using price mechanisms and some other approaches. Besides these approaches, organizations should have enough concentration on customer and should develop its' strategies from customers' viewpoint and understand the relationship among the market position, customer lifetime value and company profitability. This research work has been undertaken to give an idea to the fairness organizations keeping the following issues in view:

1. How much importance customer lifetime value play in improving the market position of a particular company.

2. Shifting company's' attention from product- centered promotional program to customer- centered promotion program.

3. Making companies to think rationally to transform short term customer into long term and to try to increase the longevity of customers.

4. Giving companies the idea that customer profitability increases as customer lifetime progresses. 


\section{OBJECTIVES OF THE STUDY}

This study has been undertaken to fulfill some cluster of objectives and to help the fairness cream companies to develop a vibrant marketing strategy which will increase the longevity of its customers.

\section{Specific objective}

In spite of one general objective, there are some specific objectives to be fulfilled through this study. They are:

1. To find out whether there is any relationship exist between customer lifetime with selected factors.

2. To find out if there exists some relationship then the strength of relationship between customer lifetime with the selected factors.

3. To find out which factors play an important role in increasing or maximizing customer lifetime value.

4. To find out which are factors that proved to be non important in increasing customer lifetime value and needed to be phased out.

\section{METHODOLOGY}

\section{Type of research design}

In order to conduct this study and to find out the fruitful result, descriptive research design has been undertaken. Personal interview method has been selected to carry out survey because of the nature of the research and the benefits associated with personal interview. Questionnaire which is the only selected medium in this study is structured in nature and is developed in a way that is consistent with the type of date that is required. Because of the presence of multiple variables in the questionnaire, multiple regression analysis has been conducted instead of bivariate regression.

In this study, Likert scaling technique has been used to code data. In this likert scaling technique, 5 response categories have been used ranging from 1 (minimum) to 5 (maximum). The label of these 5 response categories are like $1=$ strongly disagree, $2=$ Disagree, $3=$ Neutral, $4=$ Agree and 5= Strongly agree .

\section{Sampling design}

The study has been carried on the fairness cream users of Bangladesh where the motive has been to find out the way to maximize the customer lifetime value. 
As a result of the nature and scope of the study, all the fairness cream users of Bangladesh have been the population of this study.

Household numbers or plot numbers of Bangladeshi residents have been the sampling frame of this study. These household numbers are the existing numbers that has been given by Bangladeshi government to locate a particular house.

Simple random sampling under probability sampling technique has been used to select samples. In this technique, every household has been given a unique identity number and all the samples have been drawn from these identity numbers through a random procedure.

The total of 300 samples have been selected to conduct the study and the numbers have been taken with the understanding of time, required size for the fruitfulness of the study and the money constraints.

\section{Data analysis}

With the purpose of the study and the model of the research design that has been used to fulfill the objective of the study, multiple regression technique has been used. In multiple regression analysis, two types of data are usually captured that are metric dependent variable and metric independent variable. These two types of data have been used to measure the existence of relationship and to measure the strength of relationship between usage month (metric dependent variable) and the international recognition of the fairness cream brand, advertisement about the potentiality of the product, all the members of household use same kind of brand, good market image, brighter skin, fear of experiment, best brand of the market (metric independent variable). Simply it can be said that, through this multiple regression analysis, I have tried to find out, how fairness cream customer's months of attachments with particular brand can be increased.

\section{Interpretation}

The data has been interpreted through a predetermined structured procedure where statistical outcomes have been analyzed through hypothesis, significance, degree of importance of the independent variables and the strength of association testing. Interpretation has been generalized based on statistical findings. The strength and significance of relationship between customer usage months belonging to particular brand and other selected variables have been measured through the output given by statistical program. In this analysis, it has been considered that more usage of particular brand means higher customer lifetime 
value. By analyzing all the variables through multiple regression technique, clear indication is possible that either a strong relationship between dependent \& independent variables exists or not. After interpreting about the strength of relationship, degree of importance of each independent variable has been interpreted through the same multiple regression technique.

Another interpretation has been done through hypothesis. Through hypothesis testing, significance of relationship between dependent variable and independent variables have been analyzed.

\section{FINDINGS AND ANALYSIS}

The findings are very important from the perspective of the study because the nature of the findings will act as a deciding factor about the proposed strategy development for fairness cream companies to improve the customer lifetime value.

TABLE 6.1

MULTIPLE REGRESSION MODEL SUMMARY: FAIRNESS CREAM USAGE (DEPENDENT VARIABLE) AND INTERNATIONAL RECOGNITION, ADVERTISEMENT ABOUT POTENTIALITY OF PRODUCT AND OTHERS (INDEPENDENT VARIABLES)

\begin{tabular}{|c|c|c|c|c|}
\hline Model & $\mathrm{R}$ & R Square & $\begin{array}{c}\text { Adjusted R } \\
\text { Square }\end{array}$ & $\begin{array}{c}\text { Std. Error of the } \\
\text { Estimate }\end{array}$ \\
\hline 1 & $.963^{\mathrm{a}}$ & .927 & .915 & 7.126 \\
\hline
\end{tabular}

a. Predictors: (Constant), International recognition, Advertisement about potentiality of product, all the members of household use same kind of brand, Good market image, Brighter skin, Fear of experiment, Best brand of the market

\section{b. Dependent Variable: Usage Months}

This model summary gives a comprehensive idea about the applicability of the regression analysis in providing findings about customer lifetime value of fairness cream users of Bangladesh.

The $\mathrm{R}$ value is 0.963 ; statistically this value is the proof of existence of correlation. As a result it can be said there is a high degree of correlation between usage months with advertisement about potentiality of product, household users 
same, good market image, brighter skin, fear of experiment, best brand of the market, international recognition. The existence of correlation is very important because the existence tells that increasing or decreasing of usage months is because the presence of the dependent variables.

The $\mathrm{R}^{2}$ value tells that how much of the dependent variable usage months can be changed by the independent variables e.g. advertisement about potentiality of product, all the members of household use same kind of brand, good market image, brighter skin, fear of experiment, best brand of the market, international recognition. In this case, the regression results indicate that $92.7 \%$ of the usage months can be changed by the independent variables.

The adjusted $\mathrm{R}^{2}$ value indicates the impact of the addition of other independent variables on dependent variable. If the adjusted $\mathrm{R}^{2}$ value is close to the value of $R^{2}$ then it does mean that addition of other independent variables increase customer usage months of particular brand. Here the value of adjusted

$\mathrm{R}^{2}$ is .915 which is close to the value of $\mathrm{R}^{2}(.927)$ and it does mean that the addition of other independent variables increase customer usage months.

\section{Significance testing}

$\mathbf{H}_{0}: \mathbf{R}_{\text {pop }}^{2}=\mathbf{0}$ (There is no relationship between customer usage months with advertisement about potentiality of product, all the members of household use same kind of brand, good market image, brighter skin, fear of experiment, best brand of the market, international recognition).

$\mathbf{H}_{1}: \mathbf{R}_{\text {pop }}^{\mathbf{2}} \neq \mathbf{0}$ (There is a significant relationship between customer usage months with advertisement about potentiality of product, all the members of household use same kind of brand, good market image, brighter skin, fear of experiment, best brand of the market, international recognition). 
TABLE 6.2

ANOVA: FAIRNESS CREAM USAGE (DEPENDENT VARIABLE) AND INTERNATIONAL RECOGNITION, ADVERTISEMENT ABOUT POTENTIALITY OF PRODUCT AND OTHERS (INDEPENDENT VARIABLES)

\begin{tabular}{|c|c|c|c|c|c|c|}
\hline & Model & Sum of Squares & Df & Mean Square & $\mathrm{F}$ & Sig. \\
\hline & Regression & 27273.480 & 7 & 3896.211 & 76.719 & $.000^{\mathrm{a}}$ \\
\hline & Residual & 2133.000 & 292 & 50.786 & & \\
\hline & Total & 29406.480 & 299 & & & \\
\hline
\end{tabular}

a. Predictors: (Constant), International recognition, Advertisement about potentiality of product, all the members of household use same kind of brand, Good market image, Brighter skin, Fear of experiment, Best brand of the market

b. Dependent Variable: Usage Months

The above ANOVA Table will give necessary information to approve one hypothesis and to reject another one.

Statistically, if the ANOVA table shows that the significant value is .0000 , it will be meant that the H0 (null hypothesis) be rejected. On the other hand, it will be meant that $\mathrm{H} 0$ (null hypothesis) be accepted.

So the final finding is that there is a significant relationship between customer usage months with advertisement about potentiality of product, household users same, good market image, brighter skin, fear of experiment, best brand of the market, international recognition. 
TABLE 6.3

FAIRNESS CREAM USAGE: ESTIMATION OF IMPORTANCE OF INDEPENDENT VARIABLES

Coefficients

\begin{tabular}{|c|c|c|c|c|c|c|}
\hline & \multirow[b]{2}{*}{ Model } & \multicolumn{2}{|c|}{$\begin{array}{c}\text { Unstandardized } \\
\text { Coefficients } \\
\end{array}$} & \multirow{2}{*}{\begin{tabular}{|c|}
$\begin{array}{c}\text { Standardized } \\
\text { Coefficients }\end{array}$ \\
Beta \\
\end{tabular}} & \multirow[b]{2}{*}{$\mathrm{t}$} & \multirow[b]{2}{*}{ Sig. } \\
\hline & & B & Std. Error & & & \\
\hline \multirow[t]{8}{*}{1} & (Constant) & -9.641 & 7.452 & & -1.294 & .203 \\
\hline & Good market image & .709 & 1.191 & .028 & .595 & .555 \\
\hline & Brighter skin & -3.281 & 1.656 & -.095 & -1.981 & .054 \\
\hline & $\begin{array}{l}\text { Advertisement about } \\
\text { potentiality of product }\end{array}$ & .443 & 1.228 & .016 & .361 & .720 \\
\hline & Fear of experiment & 5.247 & 1.389 & .288 & 3.778 & .000 \\
\hline & Best brand of the market & 6.572 & 1.514 & .400 & 4.340 & .000 \\
\hline & $\begin{array}{l}\text { all the members of } \\
\text { household use same kind } \\
\text { of brand }\end{array}$ & -.003 & 1.328 & .000 & -.002 & .998 \\
\hline & International recognition & 6.335 & 1.439 & .377 & 4.401 & .000 \\
\hline
\end{tabular}

a. Dependent Variable: Usage Months

The above model is very important to develop customer lifetime model and to find out the factor or factors that are crucial to increase customer lifetime.

Customer lifetime $=-9.641+.709($ Good market image $)+-3.281$ (Brighter skin) +.443 (Advertisement about potentiality of product) +5.247 (Fear of experiment) +6.572 (Best brand of the market) +-.003 (all the members of household use same kind of brand) +6.335 (International recognition)

Among independent variables, three variables have been found statistically significant for increasing customer lifetime value. These three variables are:

1. Fear of experiment

2. Best brand of the market and

3. International recognition

Customers' usage months or customer lifetime value can be increased through proper application of these three variables. From these three variables, 
fear of experiment resides in the minds of customers and marketers can exploit this opportunity and create some sort of fear that changing existing brand may be hazardous for their skin. Although applying this strategy may face some legal problems in reality.

In case of other two variables, marketers should take proper attempts to prove themselves that they are the best brand in the market and they have international familiarity. In this case global brands which are operating in Bangladesh will get clear advantage. On the contrary, it will be an unfavorable message and bad ones for local companies.

FIGURE 6.1: Histogram on Dependent Variable: Fairness Cream Usage Months

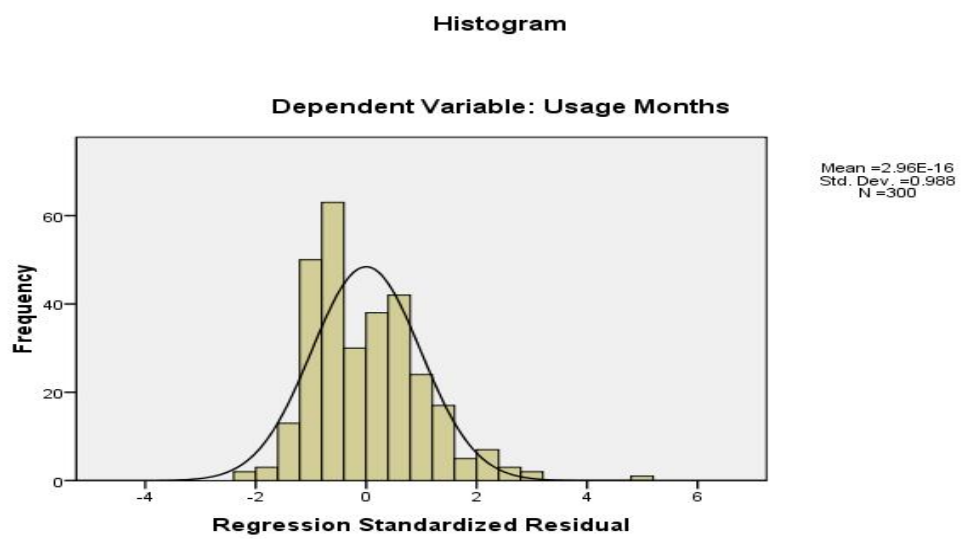

The above histogram shows that standard deviation is not high enough to raise question about the response variation. Mean value is positive and high, and there is no unusual deviation. 
FIGURE 6.2: Normal P-P Plot of Regression Standardized Residual for Fairness Cream: Usage Months (Dependent Variable)

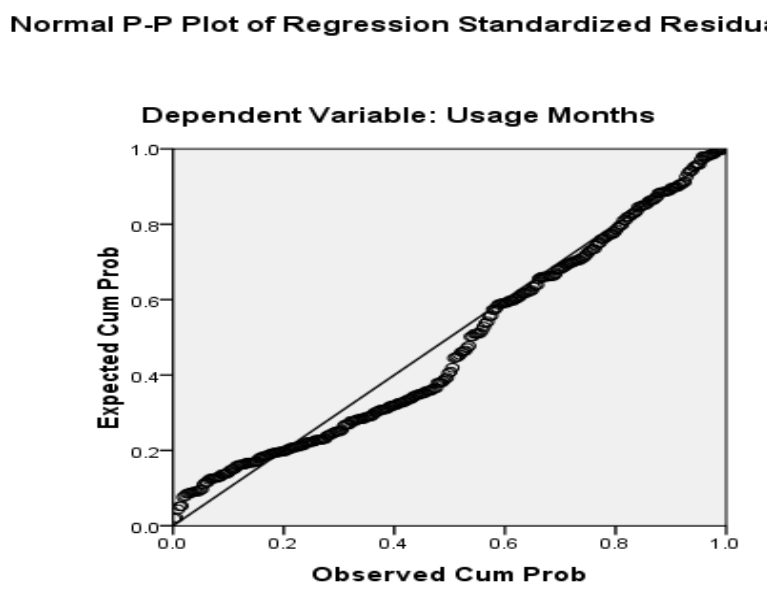

The above scatter diagram (Figure 6.2) gives an idea about the form of relationship between dependent and independent variables. It shows the form of relationship between customer usage months of particular brand with advertisement about potentiality of product, all the members of household use same kind of brand, good market image, brighter skin, fear of experiment, best brand of the market, international recognition. From this scatter diagram it can be said that there is some sort of unusual variations among the respondents.

\section{CONCLUSIONS}

Today's competitive market does not give any room to correct the mistakes committed by companies. But our country's fairness cream companies are doing mistakes by not appreciating the importance of customer lifetime value. A company's profitability can be increased by nurturing existing customers and increasing their lifetime. Marketers will have to take informed strategic decision to increase customer lifetime value. From the above analysis, some recommendations or suggestions are given to fairness cream companies that may help them to improve their position in the market for their products.

- From theoretical viewpoint it can be said that increasing customer lifetime will increase company profitability. So marketer will have to act according to this theory.

- From the analysis it has been found that there is a good relationship between customer usage months of a particular brand or customer 
lifetime with advertisement about potentiality of product, all the members of household use same kind of brand, good market image, brighter skin, fear of experiment, best brand of the market. So marketer can think about these factors and develop marketing strategy on the basis of these factors.

- From all the independent variables, three variables have been found as important for making customers sustaining for longer time. So marketers should attach more attention to these variables.

- Fear of experiment is one of these three variables. Customer wants to stick with particular brand because he or she fears that frequent changing of fairness cream may be dangerous for his or her skin. Marketer should develop a suitable strategy to retain its existing customers through using this fear.

- Perception that the brand that customer is using is the best brand in the market is another one of these three important variables. So marketer should position this belief in the heart of customers and constantly work on this issue.

- The last of three important variables is the international recognition of the brand. It does mean that brands that have international recognition influences customers to stick with their existing brands. So international recognition of brands helps to increase customer lifetime value and marketers should leverage this kind of international recognition in their promotional program and should position it in the heart of customers. 


\section{REFERENCES}

Fader, Hardie and Ka Lok Lee (2005), "RFM and CLV: Using Iso- CLV Curves for Customer Base analysis," Journal of Marketing Research, Vol. 42, pp. 415-30.

Gupta, Sunil and Donald R. Lehmann (2003), "Customers as Assets," Journal of Interactive Marketing, Vol. 17, No. 1, pp. 9-24.

Gupta S. and Hanssens D. and Hardie B. and Kahn W. and Kumar V. and Lin N. Ravishanker N. and Sriram S. (2006), "Modeling customer lifetime value," Journal of Service Research, Volume 9, No. 2, pp. 139-155.

Gupta, Sunil and Jennifer Ames Stuart (2004), "Valuing Customers," Journal of Marketing Research, Vol. 41, No. 1, pp. 7-18.

http://www.franchisemastermind.com/, accessed on March 25, 2012.

Kotler, P. and Keller K. L. (2011), “Marketing Management”, Pearson Prentice Hall, 13 ${ }^{\text {th }}$ edition, p. 132.

Kumara V. and Rajan B. (2009), "Profitable customer management: Measuring and maximizing customer lifetime value," Management accounting quarterly, Vol. 10, No. 3 pp. 1-18.

Reinartz, Werner and Kumar V. (2000), "On the Profitability of Long- Life Customers in a Noncontractual Setting: An Empirical Investigation and Implications for Marketing," Journal of Marketing, Vol. 64, pp. 17-35.

Reinartz W. and Thomas J. S. and Kumar V. (2005), "Balancing Acquisition and Retention Resources to Maximize Customer Profitability," Journal of Marketing, Vol. 69, pp. 63-79.

Shankar, P. R. and Subish P. (2007), "Fair Skin in South Asia: An Obsession", Journal of Pakistan Association of Dermatologists, Vol.5, No. 17, pp. 100-104.

Thomas, Jacquelyn (2001), "A Methodology for Linking Customer Acquisition to Customer Retention," Journal of Marketing Research, Vol. 38, No. 2, pp. 262-68. 